\title{
Growing Eremanthus erythropappus in crushed laterite: A promising alternative to topsoil for bauxite-mine revegetation
}

\author{
Naiara Amaral de Miranda Machado a , Mariangela Garcia Praça Leite a , \\ Maurílio Assis Figueiredo ${ }^{\mathrm{a}}$, Alessandra Rodrigues Kozovits ${ }^{\mathrm{b}, *}$ \\ a Department of Geology, Federal University of Ouro Preto, 35.400-000 Ouro Preto, Minas Gerais, Brazil \\ ${ }^{\mathrm{b}}$ Laboratory of Plant Ecophysiology, Department of Biodiversity, Evolution and Environment, Campus Morro do Cruzeiro, Federal University of Ouro Preto, \\ 35400-000 Ouro Preto, Minas Gerais, Brazil
}

\section{A R T I C L E I N F O}

\section{Article history:}

Received 25 March 2012

Received in revised form

7 July 2013

Accepted 14 July 2013

Available online 3 August 2013

\section{Keywords:}

Allometry

Canga

Eremanthus erythropappus

Particles size reduction

Iron duricrust

Relative growth

Revegetation

\begin{abstract}
A B S T R A C T
Topsoil is the preferred substrate for areas requiring rehabilitation after bauxite mining. However, topsoil is sometimes lacking and so there is a need to test the suitability of other, locally available substrates. In an abandoned bauxite mine in Southeastern Brazil, small patches of native vegetation spontaneously established in shallow depressions over weathered laterite, suggesting that granulometric reduction may have facilitated the establishment of plants. To test this hypothesis, blocks of laterite collected in the area were crushed to simulate texture observed in the vegetation patches. Topsoil collected in a preserved ferruginous field near to the extraction area was also used as a substrate in which Eremanthus erythropappus seedlings, a native woody species, were grown. Seedlings were cultivated without fertilizers in these two substrates and also directly over the exposed and uncrushed laterite. The species proved to be very promising for the revegetation, showing a high survival rate in all substrates. Higher annual growth rates and higher final biomass values were observed in topsoil, but the granulometric reduction of laterite doubled plant growth rate in comparison to the exposed laterite. This result was likely due to the increased availability of essential nutrients to plants and to the improvement in physical conditions for root growth and functioning. Moreover, seedling allometry was not altered by the type of substrate, suggesting that the species was highly tolerant to the new substrate conditions, a fundamental characteristic for success of revegetation of bauxite extraction degraded areas.
\end{abstract}

(c) 2013 Elsevier Ltd. All rights reserved.

\section{Introduction}

The world's largest bauxite deposits (reserves) are found in Australia and Brazil, which are also the major producers (IBRAM, 2010). Nevertheless, bauxite is actually been produced all around the world, from Australia, passing through Africa (Guinea and Ghana), Europe (Greece and Romania), Asia (India, China, Vietnam, Iran and Russia), South America (mostly in Brazil and Venezuela) and Caribbean (Jamaica and Cuba). Despite of its substantial economic benefits, mining practices result in a degradation of thousands of hectares of land around the world. A single bauxite mine can be responsible for the degradation of up to 100 ha of land per year (Bradshaw, 2002). From all the impacts caused by mining activity, the complete removal of vegetation and superior soil layers are particularly destructives to natural ecosystems. These factors make it difficult for an area to regenerate naturally and

\footnotetext{
* Corresponding author. Tel.: +55 3135591265 .

E-mail addresses: arkozovits@gmail.com, kozovits@iceb.ufop.br (A.R. Kozovits).
}

consequently interventions are required in order to re-establish the ecological trajectory of the system (Palmer et al., 1997). Among the mostly tested methods, recovering of degraded surfaces with topsoil is undoubtedly the most efficient in restoring as the soil layer act as a source of organic matter and microorganisms, and can function as seed bank (Hall et al., 2009). However, in many mining areas, topsoil is very thin and usually is not stocked or lengthy storage periods greatly reduce its regenerative potential. Consequently, a large number of mines remain abandoned with no effective restoration efforts (Bradshaw, 1997; Tordoff et al., 2000). In addition, several factors restrict the establishment of seedlings and inhibit the growth of plant roots, including the hardness and density of the regolith, the high concentration of heavy metals and the low availability and retention of nutrients and water (Mengler et al., 2006). For this reason, it is necessary to look for alternative techniques to facilitate the establishment and development of vegetation (Kew et al., 2007).

An alternative approach to optimize the process of revegetation for commercial purposes or for restoration of mined areas lacking 
topsoil is the use of available waste material, crushed to enable plants fixation and the use of indigenous species. Plants which have evolved on the shallow and metal-rich soils of cangas (Brazilian name for iron duricrusts), for example, might be more adapted to edaphic and microclimatic conditions similar to those found in bauxite post-mining areas, thus establishing more successfully than non-native species. In addition, native species have the greatest potential to restore the local trophic chains, and should be preferred in actions for ecosystem restoration. Indeed, the use of native plants is the policy of many countries, including Brazil, which is now facing a huge challenge posed by new environmental laws (Aronson et al., 2011). To date, Eucalyptus has been the group of woody plants most commonly cited in short and long term revegetation studies in iron ore and bauxite post-mining areas, even in world regions where it does not occur naturally. There is currently very little information available regarding successful revegetation processes in Brazil that use native vegetation in laterite areas, other than the restoration studies of moist forests in the Amazon (Parrotta and Knowles, 1999). In this sense, this work is pioneer, bringing, as far we know, the first results on the growth of Eremanthus erythroppapus, a species that meets all requirements for the revegetation of a degraded bauxite mine area, characterized by absence of topsoil. E. erythropappus is a woody pioneer species that is naturally and widely distributed throughout Brazil, Argentina and Paraguay. The plant occurs over different lithologies, including the iron duricrusts. Its wood is hard and resistant, which is intensively used by local people. Moreover, stem has been used more recently to extract alpha bisabolol, an essential oil of great commercial value to pharmaceutical and cosmetic industries (Souza et al., 2008; Oliveira et al., 2009). This high economic potential is also another desirable attribute required by the new Brazilian environmental law, allowing a sustainable use of the area after mine closure (COPAM, 2008).

The present study was conducted in an old bauxite exploitation area, which was abandoned in the 60s without receiving any restoration efforts. Small patches of native vegetation were observed in situ, associated with laterite fractures or with small and shallow depressions containing small sized laterite particles. Along with the findings of Craw et al. (2007), this suggests that by itself, reducing the size of laterite particles can facilitate the natural establishment of native plants. The exploited area was bordered by undisturbed native vegetation spots, which were considered as reference sites (White and Walker, 1997).

Based on the characteristics of the reference site and on the natural regeneration processes of the degraded area, the crushed laterite and the collected topsoil from the reference site were tested as substrates for the growth and development of E. erythropappus seedlings. Despite the expected low fertility of laterite in comparison to the topsoil conditions, it is believed that the reduction of laterite particles size may facilitate the development of native species by changing physicochemical proprieties of the substrate compared with uncrushed laterite, offering a methodological alternative for enhancing the revegetation or restoration of bauxite and iron mines.

\section{Methods}

\subsection{Description of the study area and reference system}

Situated on the east slope of Serra da Brígida (latitude $20^{\circ} 21^{\prime} 45^{\prime \prime} \mathrm{S}$, longitude $43^{\circ} 30^{\prime} 07^{\prime \prime} \mathrm{O}$ ), east of the Quadrilátero Ferrífero in Brazil, the study area was mined for bauxite during the 1960s and has been abandoned since this time. Ferruginous fields (Jacobi et al., 2007) on the western slope of those mountains, belonging to the Serra da Brígida Environment Preservation Area, were adopted as a reference site. This site is characterized by cambisols, which formed over colluvial material with a shallow topsoil layer (thickness of up to $20 \mathrm{~cm}$ ). Herbaceous plants with islands of woody species growing in cracks or smalls depressions dominate the landscape. There are signs of spontaneous regeneration within the mining area and native species primarily colonize laterite fractures or places where the geological material is weathered. The plant species selected for the experiment, E. erythropappus (DC.) MacLeish (candeia), is widely distributed in both the reference site and in the mining area. This woody species is native to ferruginous fields and other environments in Quadrilatero Ferrífero, being particularly common in shallow and oligotrophic soils, and with high concentration of heavy metals (Scolforo et al., 2003).

Observations in the study area suggested that two possible substrates might accelerate the revegetation of the degraded area: the topsoil taken from the reference site and the "crushed laterite", which consisted of fragmented local laterite simulating the particles size distribution observed within the patches of spontaneous regeneration (see below). The development of seedlings in these two substrates was compared to that in the laterite blocks after the removal of bauxite, called "exposed laterite".

\subsection{Experimental design}

The experiment was completely randomized designed with 20 repetitions for each treatment (topsoil, crushed laterite or exposed laterite). The experimental units, plots with $0.25 \mathrm{~m}^{2}$ in size, were randomly distributed in three rows (Fig. 1). Each row presented the same number of repetitions of each treatment. Each plot was limited by a $15 \mathrm{~cm}$ high wooden board. In April 2009, after the substrates were prepared and allocated, each plot received one seedling of E. erythropappus (Fig. 2).

\subsection{Preparation and allocation of substrates}

In the center of each plot, a planting hole of approximately $10 \mathrm{~cm}$ in diameter and $10 \mathrm{~cm}$ deep was created in the laterite using an electric jackhammer. For the "exposed laterite" treatment, the

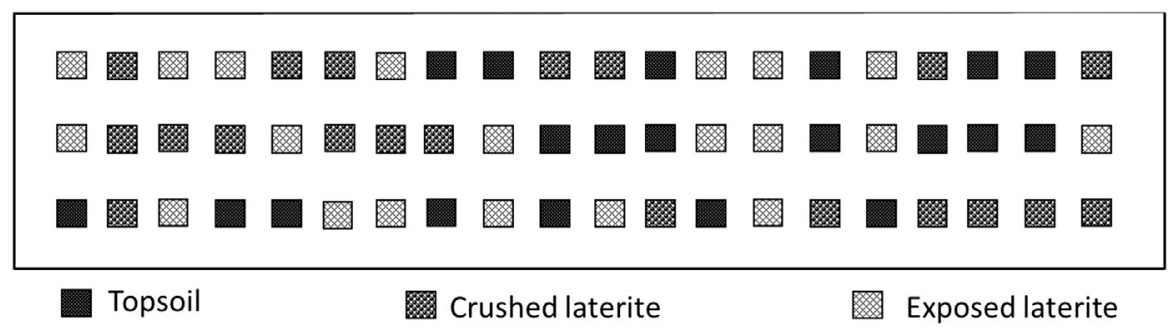

Fig. 1. Schema of the experimental design. Eremanthus erythropappus saplings were distributed into three treatments (topsoil, crushed laterite and exposed laterite). 


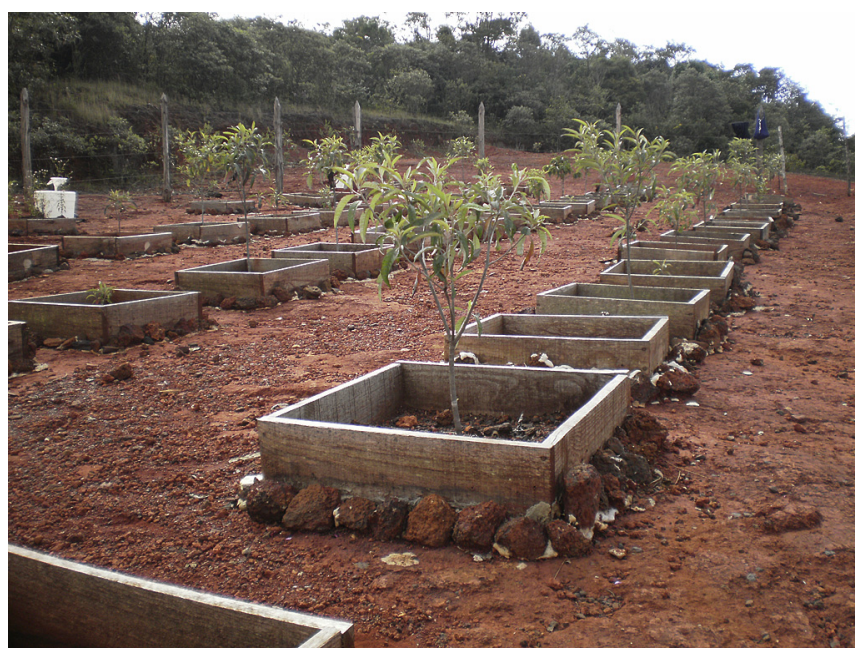

Fig. 2. Study area. Each plot contains one Eremanthus erythropappus sapling.

seedlings were planted using only the substrate taken from the planting holes. To collect the topsoil, PVC boards with the same dimensions as the study plots $(50 \times 50 \mathrm{~cm})$ were manufactured in order to define the soil area to be collected. The boards were randomly placed on the undisturbed area and the superficial soil layer was retrieved (up to $10 \mathrm{~cm}$ deep) using a shovel. This procedure was repeated 20 times, i.e., until enough topsoil volume was obtained to cover 20 plots with $0.025 \mathrm{~m}^{3}$ of soil, what resulted in a soil depth of about $15 \mathrm{~cm}$ in the center of the plot and approximately $5 \mathrm{~cm}$ in the remaining quadrant area. The material was homogenized and immediately distributed onto the plots.

To prepare the "crushed laterite", the particles size distribution of weathered laterite samples collected in seven natural regeneration spots in the study area were analyzed (Table 1). These data (Table 1) were used to guide the crushing of the laterite blocks in the laboratory, where they were crushed until the resulting material have fractions and sizes similar to that obtained in Table 1, an attempt to simulate the original topsoil. Laterite blocks were collected from the study area and were sent to the Mining Ore Treatment Laboratory (DEMIN/EM/UFOP) for fragmentation. First, the laterite blocks were crushed in a Dodge $90 \mathrm{~mm} \times 130 \mathrm{~mm}$ jaw crusher (Cimaq S.A.) and the fragmented material was weighed. The weight of each particle size fraction was then estimated from the total weight of the sample $(720.91 \mathrm{~kg})$. The fractions of gravel, grain and coarse sand were separated using 4, 2 and $1 \mathrm{~mm}$ sieves.
The material passing through the sieves was crushed again and the coarse and medium sand fractions were separated with 0.5 and $0.25 \mathrm{~mm}$ sieves. To obtain fine sand, very fine sand and silt and clay fractions, the rest of the laterite was crushed again using a Roll Crusher (Renard) and was then milled using a disc Mill. Sieves with 0.125 and $0.063 \mathrm{~mm}$ meshes were used to separate those fractions. Once was obtained a similar particles size distribution to that found for laterite from the natural regeneration spots, the "crushed laterite" was homogenized and $0.025 \mathrm{~m}^{3}$ of this substance was distributed on each plot.

\subsection{Chemical characterization of tested substrates}

Before the seedlings were planted, five sub-samples of the three substrates were chemically analyzed. The actual $\mathrm{pH}$ values were determined in a soil suspension of 1:2.5 (v/v) distilled water, $1 \mathrm{~h}$ after stirring. Total nitrogen was determined by Kjeldahl method, following the standard methods adopted by the Brazilian Research Center for Agriculture (Bremner, 1960). The total content of organic matter was determined using Walkley-Black method (1934)

The concentrations of trace elements and macro-nutrients of tested substrates were measured by total digestion (Moutte, 2009) and sequential extraction (Rauret et al., 2001) to determine the concentrations in the different fractions that were bio-available for the plants, as well as the reducible and oxidable fractions. Five composite samples of each substrate were dried at room temperature, sieved and the fraction less than $0.063 \mathrm{~mm}$ was reserved for this analysis.

The total digestion method used concentrated fluoride acid as an extractor in subsamples of $0.25 \mathrm{~g}$ each, whereas the sequential extraction method used successive extractions with $0.11 \mathrm{~mol} \mathrm{~L}^{-1}$ ascetic acid (exchangeable fraction $-F 1$ ), $0.1 \mathrm{~mol} \mathrm{~L}^{-1}$ hydroxylamine chloride with $\mathrm{pH} 2$ (reducible fraction $-F 2$ ), $30 \% \mathrm{~m} / \mathrm{m}$ hydrogen peroxide and $1 \mathrm{~mol} \mathrm{~L}^{-1}$ ammonium acetate (oxidable fraction $-F 3$ ) in subsamples of $0.5 \mathrm{~g}$. After the extraction procedures, the trace element concentrations and the macro-nutrients were measured with an ICP-OES (Spectro/Ciros CCD).

\subsection{Soil matric potential and rainfall}

To compare the dynamics of soil moisture between topsoil and crushed laterite, four resistivity-based granular matrix sensors and one temperature sensor (Watermark 200SS) were installed per treatment, at a substrate depth of $5 \mathrm{~cm}$. The sensors were installed within plots of a new study started in December 2011, conducted exactly in the same area and with the same substrates and particles

Table 1

Particles size distribution established for the preparation of the "crushed laterite" substrate.

\begin{tabular}{|c|c|c|c|c|c|c|c|c|}
\hline \multicolumn{2}{|c|}{ Wentworth (1922) size class } & \multicolumn{3}{|c|}{ Reference material and crushed laterite } & \multicolumn{4}{|l|}{ Topsoil } \\
\hline & & \multirow{2}{*}{$\begin{array}{l}\text { Average (\%) } \\
50.2\end{array}$} & \multirow{2}{*}{$\begin{array}{l}\text { Maximum (\%) } \\
71.6\end{array}$} & \multirow{2}{*}{$\begin{array}{l}\text { Minimum (\%) } \\
28.8\end{array}$} & \multirow{2}{*}{$\begin{array}{l}\text { Average (\%) } \\
50.2\end{array}$} & \multirow{2}{*}{$\begin{array}{l}\text { Maximum } \\
(\%)\end{array}$} & & Minimum (\%) \\
\hline Gravels & $>2 \mathrm{~mm}$ & & & & & & 46.9 & \\
\hline Very coarse sands & $1-2 \mathrm{~mm}$ & 8.9 & 13.0 & 6.5 & 8.9 & 9.6 & 8.2 & \\
\hline Coarse sands & $0.5-1 \mathrm{~mm}$ & 8.7 & 13.3 & 6.0 & 8.7 & 9.3 & 8.1 & \\
\hline Medium sands & $0.25-0.5 \mathrm{~mm}$ & 9.3 & 13.2 & 6.0 & 9.3 & 10.2 & 8.4 & \\
\hline Fine sands & $0.125-0.25 \mathrm{~mm}$ & 8.6 & 12.3 & 5.1 & 8.6 & 9.5 & 7.7 & \\
\hline Very fine sands & $0.0625-0.225 \mathrm{~mm}$ & 8.5 & 11.2 & 5.2 & 8.5 & 9.3 & 7.7 & \\
\hline Silts and clays & $<0.0625 \mathrm{~mm}$ & 5.8 & 9.9 & 2.7 & 5.8 & 6.4 & 5.2 & \\
\hline
\end{tabular}


sizes as used in 2009 (present study). The resistance readings were taken every 60 min and converted by Watermark monitor software, that comes with the datalogger (model $900 \mathrm{~m}$ ), to soil matric potential (Shock et al., 1998). Data are presented as mean values per week between January 26 and October 5, to demonstrate the soil matric potential behavior during the rainy and dry seasons. Precipitation was measured by a weather station (WacthDog 2800) installed at about $500 \mathrm{~m}$ of the experimental area.

\subsection{Planting and development of seedlings}

Four-month old E. erythroppapus seedlings were provided by the IEF (Minas Gerais State Forest Institute) and had an average height of $10 \mathrm{~cm}$. After planting, the only treatment applied was a weekly irrigation (500 $\mathrm{ml}$ of water per seedling) during the dry season (April-October 2009), simulating a minimum monthly rainfall of eight $\mathrm{mm}$.

The stem height and diameter were measured at planting (in April 2009) and after 12 months (in April 2010). The growth rate (height and diameter) for a period of one year was calculated according to the formula GR $=(\varnothing f-\emptyset i) / \varnothing i \times 100$, where $\emptyset f$ indicates the stem height or diameter at the end of the experiment and $\emptyset i$ indicates the value at the beginning of the experiment. After 12 months, the seedlings were collected, all on the same day, washed and separated into leaves, stem and branches, and roots. The samples were dried at $65^{\circ} \mathrm{C}$ until reaching a constant weight and the dry biomass of the leaves, stem and branches and roots was assessed.

The survival rate was calculated for each treatment by subtracting the number of individuals initially planted by the difference between the initial and final individuals living, and the final result was divided by 100 .

\subsection{Statistical analysis}

The fertility data and the $\mathrm{pH}$ of substrates were evaluated using a single-factor ANOVA where the treatments (substrates) were the fixed factor. Data on the concentration and distribution of macroand trace elements obtained through sequential extraction were log-transformed and assessed using a Principal Component Analysis (PCA) using the software PAST (Hammer et al., 2001). For each variable were measured distance values $(d)$ of each coordinate point variable with respect to the axes of the graph resulting from the analysis, using the formula: $d \geq \sqrt{ } 2 / n$, where $n$ is the number of variables in the model (Valentin, 2000), in this case $n$ was 18 and $d$ was 0.333 . The differences on matric potential averages between topsoil and crushed laterite were tested separately for the dry and rainy seasons through Wilcoxon test. Beyond that, three multivariate analyzes of variance (MANOVA) were performed to evaluate the differences in the mean concentration of elements in exchangeable fraction $(F 1)$, non-exchangeable ( $F 2$ and $F 3$ ) and total.

Four single-factor variance analyses (with substrates as fixed factor) were used to detect differences in total biomass, roots, stems and foliage biomass. These data were also log-transformed. A covariance analysis was used to detect the effect of different substrates on the allometric relationships of seedlings, where the dependent variable $(y)$ was the biomass of a compartment (root, stem, foliage) and the co-variable ( $x$ ) was the biomass of another compartment (Muller, 2000). The biomass data were logtransformed. Thus, the linear regression $\log (Y)=\log (\alpha)+\beta \log (X)$ was used for covariance analysis, which is the logarithmic transformation of the classic allometric equation $Y=\alpha X^{\beta}$, where $\beta$ is the allometric exponent and $\alpha$ is the allometric coefficient (Huxley, 1932).
The growth rates in the height and diameter of the seedlings were assessed using variance analyses with substrate treated as a fixed factor. To minimize the effect of the initial size of the plant on the growth variables, the initial height was used as a co-variable.

\section{Results}

The $\mathrm{pH}$ in topsoil was significantly lower $\left(F_{2 ; 12}=30.22\right.$; $p<0.001$ ) when compared to values in crushed and exposed laterites (Table 2), reflecting the differences found in organic matter $\left(F_{2 ; 12}=29.92 ; p<0.001\right)$, which was much higher in topsoil. Topsoil has presented twenty two times higher total nitrogen content $(t=9.82 ; p<0.001)$.

The total, the exchangeable $(F 1)$ and non-exchangeable fractions (F2 and F3) concentrations of elements for each substrate are separated in Table 2 for essential, non-essential, macro- and micronutrients according to the demands of plant tissues (Marschner, 1986). The results of multivariate analyzes of variance (MANOVA) showed that the concentration of most elements differ between the substrates in fraction exchangeable $\left(F_{24 ; 2}=332,214.9 ; p<0.001\right)$, non-exchangeable $\left(F_{36 ; 20}=38,993.58 ; p<0.001\right)$ and total $\left(F_{24 ; 2}=13,525.54 ; p<0.01\right)$. The results of univariate analyzes indicating elements that differ significantly between the substrates was included in Table 2.

The concentrations of $\mathrm{Al}, \mathrm{As}, \mathrm{Bi}$ and Fe were much higher than those commonly observed for superficial soils in other regions (Kabata-Pendias and Pendias, 2001; see Table S1 in Supplementary material). However, among those elements, only $\mathrm{Al}$ and Fe were present in the soil available phase $(F 1)$ or in the potentially available phase $(F 2+F 3$; Table 2$)$. On the other hand, elements that are important for the development of plants, such as $\mathrm{Ca}, \mathrm{K}, \mathrm{Mg}$ and $\mathrm{Na}$, showed much lower concentrations than the commonly observed. Considering the results for $F 1$, topsoil showed the highest values for all essential macro- and micro-nutrients other than $\mathrm{Cu}$, and also the higher concentrations for most non-essential elements, including $\mathrm{Al}, \mathrm{Ba}, \mathrm{Na}$ and $\mathrm{Sr}$. In the non-exchangeable fractions (F2 and F3), the highest concentrations of some micro-nutrients (Fe, $\mathrm{Mn}$ and $\mathrm{Zn}$ ) and non-essential elements were also observed in the topsoil. On the other hand, crushed laterite showed higher concentrations of macro-nutrients $\mathrm{Mg}$, P and $\mathrm{S}$ and micro-nutrient $\mathrm{Cu}$ than the other substrates. Trace elements, such as Ti and V, were only observed in the unchangeable fractions $(F 2+F 3)$. Comparing only the treatments with laterite, crushed laterite shows the highest concentration of all detectable macro- and micro-nutrients in the exchangeable fraction, suggesting that the particles size reduction of laterite increased the nutrient availability, probably as a result of surface area enlargement (Berrow et al., 1978).

The principal component analysis (PCA) applied to the soil data of the sequential extraction (Table 2 ) reduced the data set to two main factors that explained $72.8 \%$ of the variability of the data. The first PCA component (eigenvalue $=3.15$; explained variation $=46.1 \%$ ) separated the topsoil from the other treatments and Fe, Mn and S were strongly correlated with this component (Fig. 3).

The matric potential behaved similarly in both substrates (Fig. 4), with average values of approximately $-20.5 \mathrm{kPa}$ and $-28.2 \mathrm{kPa}$, in topsoil and crushed laterite, respectively, during the rainy season, and reaching 186.9 and $201.9 \mathrm{kPa}$ in the dry season. Although the averages did not differ significantly between substrates (dry season $-W=125, p=0.61$; rainy season $-W=319$, $p=0.072$ ), the matric potential in crushed laterite seems to respond more quickly and sharply to rainfall reduction (Fig. 4).

Survival rates of more than $80 \%$ were found in all of the substrates, with survival rates as high as $95 \%$ observed in the topsoil. The substrates also significantly influenced root $\left(F_{2} ; 48=91.821\right.$; $p>0.001)$, stem $\left(F_{2} ; 48=131.91 ; p>0.001\right)$ and foliage biomass $\left(F_{2}\right.$; 
Table 2

Total, exchangeable $(F 1)$ and non-exchangeable fractions ( $F 2$ and $F 3)$ concentrations $\pm \mathrm{SD}$ of elements $\left(\mathrm{mg} \mathrm{kg}^{-1}\right)$ presents on topsoil, crushed and exposed laterite, $\mathrm{pH}$ and $\mathrm{OM}\left(\right.$ organic matter $\left.-\mathrm{g} \mathrm{kg}^{-1}\right)$. Symbol $(-)$ indicates values below the detection limit.

\begin{tabular}{|c|c|c|c|c|c|c|c|c|c|}
\hline \multirow[t]{2}{*}{ Element } & \multicolumn{3}{|l|}{ Topsoil } & \multicolumn{3}{|l|}{ Crushed } & \multicolumn{3}{|l|}{ Exposed } \\
\hline & $F 1$ & $F 2+F 3$ & Total & $F 1$ & $F 2+F 3$ & Total & $F 1$ & $F 2+F 3$ & Total \\
\hline $\mathrm{pH}$ & & & 4.66 & & & 5.57 & & & 5.30 \\
\hline $\mathrm{OM}$ & & & 8.46 & & & 0.00 & & & 0.00 \\
\hline \multicolumn{10}{|c|}{ Macronutrients } \\
\hline $\mathrm{Ca}$ & $135.46 \pm 6.32^{*}$ & $42.39 \pm 16.37^{* *}$ & $197.13 \pm 15.25$ & $28.28 \pm 2.65^{*}$ & $41.75 \pm 12.98^{* *}$ & $20.77 \pm 8.18$ & - & $5.84 \pm 4.40^{* *}$ & - \\
\hline $\mathrm{K}$ & $93 \pm 4.17^{*}$ & $27.05 \pm 14.21^{* *}$ & $400.93 \pm 6.5$ & $8.45 \pm 3.35^{*}$ & $2.8 \pm 1.09^{* *}$ & $514.77 \pm 13.6$ & $3.91 \pm 1.04^{*}$ & $3.48 \pm 1.39^{* *}$ & $393.63 \pm 43.45$ \\
\hline $\mathrm{Mg}$ & $43.54 \pm 2.09^{*}$ & $3.75 \pm 0.64^{* *}$ & $322.58 \pm 8.72$ & $16.1 \pm 15.98^{*}$ & $6.04 \pm 1.83^{* *}$ & $263.3 \pm 6.7$ & $1.87 \pm 0.44^{*}$ & $0.16 \pm 0.16^{* *}$ & $237.86 \pm 32.74$ \\
\hline $\mathrm{P}$ & $5.24 \pm 1.75^{*}$ & $3.92 \pm 3.47^{* *}$ & $1161.4 \pm 11.39$ & - & $7.2^{* *}$ & $378.98 \pm 7.26$ & - & - & $423.4 \pm 20.53$ \\
\hline $\mathrm{s}$ & $35.36 \pm 15.58^{*}$ & $70.1 \pm 70.5^{* *}$ & $693.84 \pm 27.59$ & - & $213.73 \pm 5.52^{* *}$ & $186.94 \pm 7.22$ & - & $10.53 \pm 3.25^{* *}$ & $118.68 \pm 41.4$ \\
\hline $\mathrm{N}$ & & & $4.10 \pm 0.89$ & & & $0.18 \pm 0.08$ & & & $0.18 \pm 0.08$ \\
\hline \multicolumn{10}{|c|}{ Micronutrients } \\
\hline $\mathrm{Cu}$ & - & $1.11 \pm 2.57^{* *}$ & $25.55 \pm 14.06$ & $1.18 \pm 1.07$ & $4.72 \pm 0.46^{* *}$ & $14.46 \pm 1.24$ & - & - & $13.76 \pm 2.89$ \\
\hline $\mathrm{Fe}$ & $36.8 \pm 47.79^{*}$ & $3123.2 \pm 1009.74^{* *}$ & $260,678.4 \pm 12448.6^{\mathrm{a}}$ & - & $1466.66 \pm 121.91^{* *}$ & $206,123.2 \pm 2640.2^{\mathrm{a}}$ & $1.87 \pm 1.07^{*}$ & $306.73 \pm 134.82^{* *}$ & $182,305 \pm 133,71.0^{\mathrm{a}}$ \\
\hline $\mathrm{Mn}$ & $360.8 \pm 31.93^{*}$ & $622.3 \pm 344.59^{* *}$ & $1738.8 \pm 247.72$ & $9.82 \pm 11.88^{*}$ & $15.83 \pm 1.23^{* *}$ & $497.3 \pm 9.88$ & $1.03 \pm 0.43^{*}$ & $0.99 \pm 0.67^{* *}$ & $344.92 \pm 14.92$ \\
\hline $\mathrm{Na}$ & $11.72 \pm 2.47^{*}$ & $39.82 \pm 18.64$ & $100.5 \pm 3.05$ & $4.29 \pm 3.97^{*}$ & $35.72 \pm 20.75$ & $76.92 \pm 3.73$ & - & $39.06 \pm 20.6$ & $54.66 \pm 9.05$ \\
\hline $\mathrm{Zn}$ & $7.36 \pm 4.27^{*}$ & $4.96 \pm 2.39^{* *}$ & $62.05 \pm 10.97^{\mathrm{b}}$ & $5.46 \pm 3.79^{*}$ & $2.01 \pm 0.6$ & $54.59 \pm 4.43^{\mathrm{b}}$ & $0.88 \pm 0.29^{*}$ & $0.42 \pm 0.17$ & $46.9 \pm 2.84^{\mathrm{b}}$ \\
\hline \multicolumn{10}{|c|}{ Nonessentials } \\
\hline $\mathrm{Al}$ & $1898 \pm 134.52^{*}$ & $5703.4 \pm 1090.02^{* *}$ & $103,241.8 \pm 2274.32$ & $264.94 \pm 3.67^{*}$ & $3896.6 \pm 98^{* *}$ & $215,169.2 \pm 1595.18$ & $617 \pm 34.43^{*}$ & $1527.1 \pm 204.9^{* *}$ & $198,746.4 \pm 9314.91$ \\
\hline As & - & - & $55.7 \pm 0.43$ & - & - & $75.54 \pm 2.78$ & - & - & $77.18 \pm 5.61$ \\
\hline $\mathrm{Ba}$ & $5.91 \pm 0.82^{*}$ & $21.77 \pm 11.15^{* *}$ & $59.22 \pm 6.37$ & $0.22 \pm 0.03^{*}$ & $1.59 \pm 0.09^{* *}$ & $34.3 \pm 0.64$ & $0.40 \pm 0.14^{*}$ & $0.3 \pm 0.09^{* *}$ & $24.4 \pm 1.77$ \\
\hline $\mathrm{Bi}$ & - & - & $15.92 \pm 3.47$ & - & - & - & - & - & 11.03 \\
\hline Co & - & - & $20.19 \pm 0.46$ & - & - & $26.56 \pm 0.22$ & - & - & $20.43 \pm 1.63$ \\
\hline $\mathrm{Cr}$ & $1.1 \pm 0.19^{*}$ & $7.71 \pm 9.54^{* *}$ & $264.35 \pm 5.19$ & $0.55 \pm 0.3^{*}$ & $22.39 \pm 1.76^{* *}$ & $413.81 \pm 7.67$ & $1.27 \pm 0.26^{*}$ & $25.57 \pm 11.34^{* *}$ & $429.89 \pm 39.32$ \\
\hline $\mathrm{Li}$ & - & - & $1.29 \pm 0.04$ & - & - & $1.15 \pm 0.05$ & - & - & $1.73 \pm 0.23$ \\
\hline $\mathrm{Ni}$ & - & - & $26.43 \pm 0.83$ & - & - & $45.54 \pm 0.92$ & - & - & $58.66 \pm 8.97$ \\
\hline $\mathrm{Pb}$ & - & $8.9 \pm 4.96^{* *}$ & $32.97 \pm 4.16$ & $3.67 \pm 1.64$ & - & - & - & - & - \\
\hline $\mathrm{Sc}$ & - & - & $5.11 \pm 0.24$ & - & - & $8.53 \pm 0.14$ & - & - & $5.33 \pm 0.56$ \\
\hline $\mathrm{Sr}$ & $1.5 \pm 0.13^{*}$ & $1.24 \pm 0.51^{* *}$ & $35.09 \pm 0.26$ & - & $0.25 \pm 0.05^{* *}$ & $69.71 \pm 1.47$ & - & $0.05 \pm 0.04^{* *}$ & $46.41 \pm 2.64$ \\
\hline Th & - & - & $27.54 \pm 0.91$ & - & - & $29.7 \pm 0.56$ & - & - & $29.84 \pm 2.88$ \\
\hline $\mathrm{Ti}$ & - & $92.4 \pm 10.3$ & $9677.77 \pm 173.74$ & - & $20.08 \pm 48.44$ & $133,88.37 \pm 260.24$ & - & $26.93 \pm 15.31$ & $102,59.97 \pm 787.55$ \\
\hline $\mathrm{V}$ & - & $35.95 \pm 3.57^{* *}$ & $290.04 \pm 3.55$ & - & $30.44 \pm 6.52^{* *}$ & $482.42 \pm 9.3$ & - & $20.11 \pm 5.73^{* *}$ & $367.32 \pm 19.13$ \\
\hline Y & - & $0.28 \pm 0.15^{* *}$ & $12.5 \pm 0.26$ & - & - & $18.14 \pm 0.29$ & - & - & $13.18 \pm 1.09$ \\
\hline $\mathrm{Zr}$ & - & - & $293.28 \pm 4.13$ & - & - & $389.54 \pm 9.3$ & - & - & $355.72 \pm 34.81$ \\
\hline
\end{tabular}

${ }^{*}$ Means significant difference $(p<0.05)$ between the concentrations of elements in $F 1$ non-exchangeable fraction.

** Means significant difference $(p<0.05)$ between the concentrations of elements in $F 2+F 3$ exchangeable fraction

Same letters means data that not differs significantly for total concentration $(p>0.05)$ 


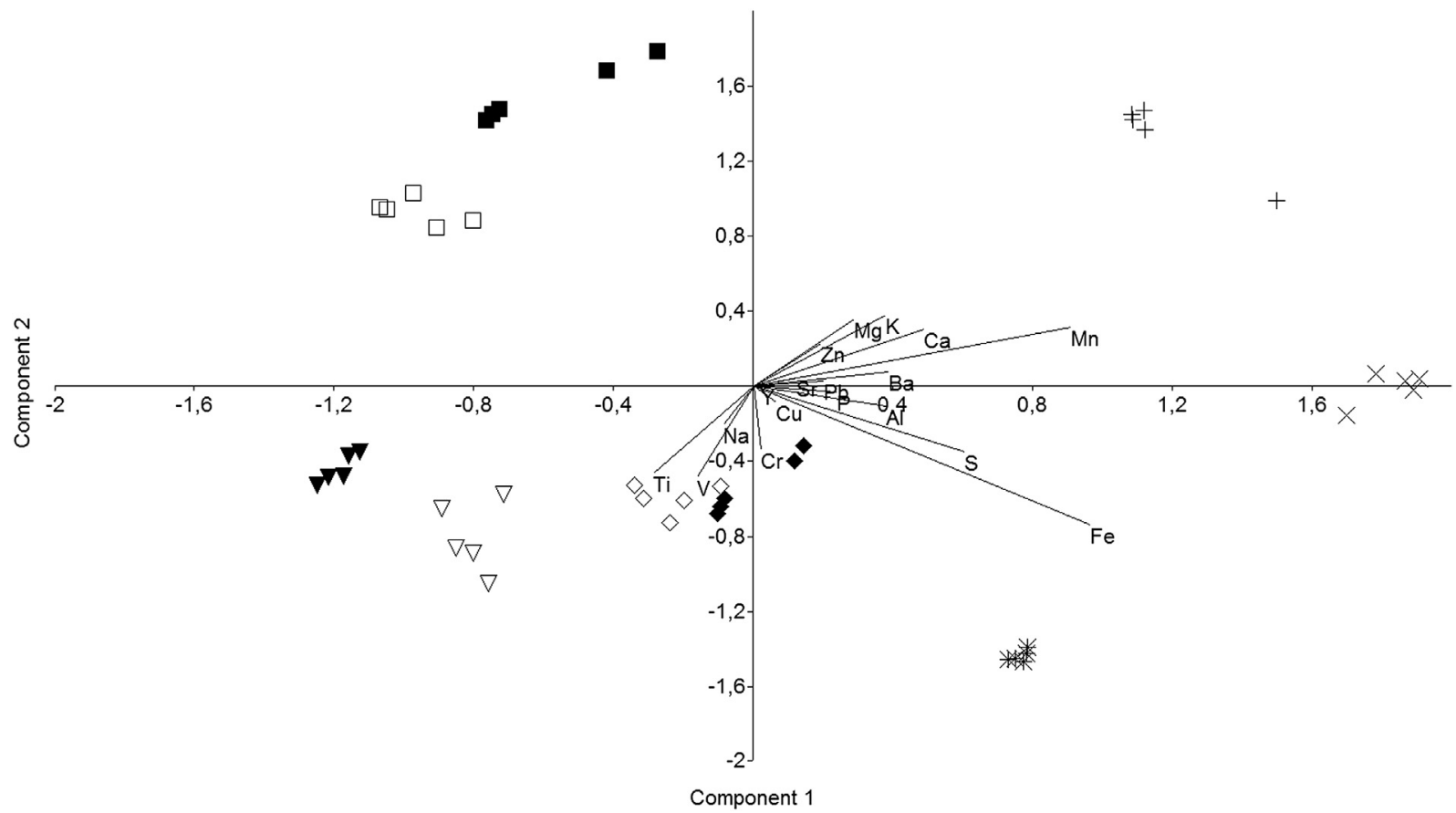

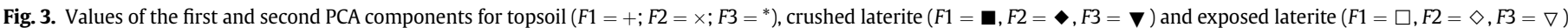

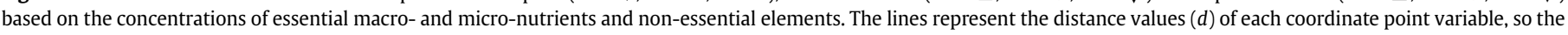
longest lines are the most highly correlated with the component. Note that $\mathrm{Fe}, \mathrm{Mn}$ and $\mathrm{S}$ are strongly correlated with the component 1 .

$48=93.851 ; p>0.001)$. The total biomass was significantly higher in the topsoil $\left(F_{2} ; 48=125.17 ; p>0.001\right)$, with an average of $63.87 \mathrm{~g} \pm 14.08 \mathrm{SD}$ compared to values of $20.13 \mathrm{~g} \pm 9.76 \mathrm{SD}$ in crushed laterite and $7.51 \mathrm{~g} \pm 4.21 \mathrm{SD}$ in exposed laterite (Fig. 5). Despite total biomass values differed, distribution among the different plant compartments (stem, leaves and roots) was similar for the three substrates, with a higher biomass occurring in the non-green parts (the stem and the roots), which together represented approximately $70 \%$ of the total biomass (Fig. 5).

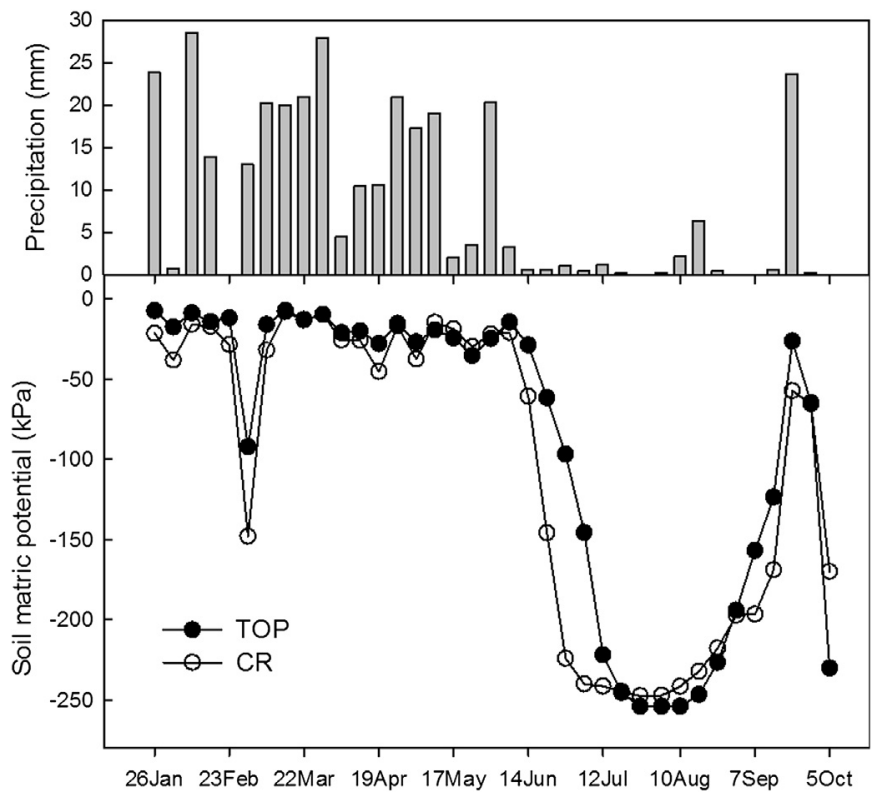

Fig. 4. Weekly precipitation $(\mathrm{mm})$ and soil matric potential $(\mathrm{kPa})$ presented as mean values per week between January 26 and October 5 in 2012, in topsoil (TOP) and crushed laterite $(\mathrm{CR})$ plots.
The type of substrate affected the final size of the plants but did not influence their allometric relationships. The root: shoot ratio did not differ significantly among substrates $\left(F_{2} ; 48=1.26 ; p>0.28\right)$ and there was no significant difference between the slopes $(\beta)$ of the linear regressions considering the relationships among the biomass of the leaves and stem $\left(F_{2 ; 45}=0.78 ; p>0.45\right)$, the leaves and roots $\left(F_{2 ; 45}=0.045 ; p>0.94\right)$ and the stem and roots $\left(F_{2 ; 45}=0.404 ; p>0.66\right)$. In general, the following single allometric relationship can be used to describe the allocation of biomass in the three tested substrates: $y=0.354+0.741 x$ for the biomass of leaves and stems; $y=0.309+0.804 x$ for leaves and roots, and $y=-0.038+1.075 x$ for the stems and roots. The substrate significantly influenced the growth in the stem height $\left(F_{2 ; 48}=13.501 ; p<0.001\right)$ and diameter $\left(F_{1 ; 48}=150.313\right.$;

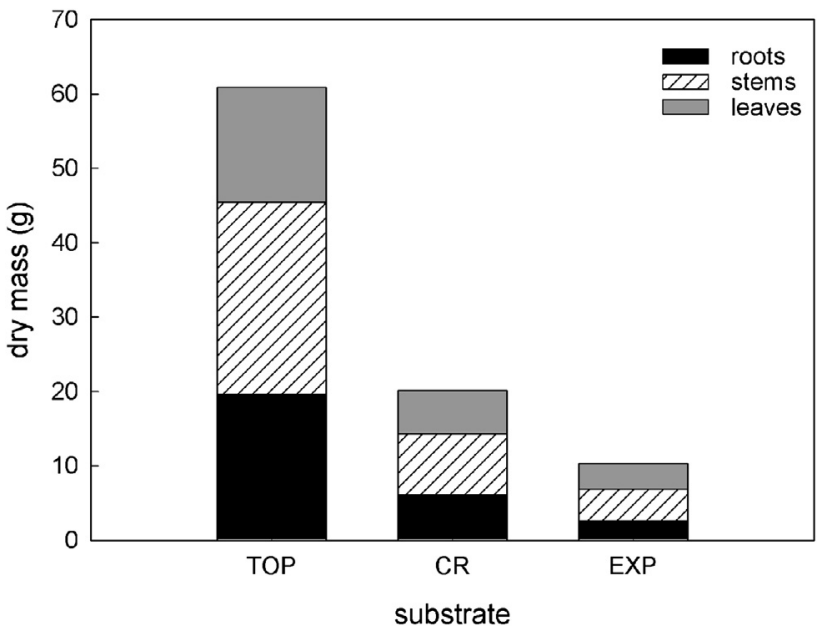

Fig. 5. Dry mass of stems, leaves and roots of seedlings of E. erythropappus after 12 months in topsoil (TOP), crushed laterite (CR) and exposed laterite (EXP), respectively. 
$p<0.001$; see Fig. $\mathrm{S} 1$ in Supplementary material) of the E. erythropappus seedlings. There was a significant difference in seedling growth in height between the topsoil and the other treatments $\left(F_{1 ; 48}=19.847 ; p<0.001\right)$. Comparing only the laterite treatments, the seedlings growth in height was approximately $190 \%$ higher for crushed laterite than for exposed laterite $\left(F_{1 ; 48}=7.155 ; p<0.01\right)$. The same pattern was observed for the growth in stem diameter, with higher values observed for plants grown in topsoil, followed by those grown in crushed laterite and exposed laterite (Fig. S1 in Supplementary material).

\section{Discussion}

Substrates physical features (such as grain size, cohesion and moisture content) play a major role in controlling mine sites revegetation (Craw et al., 2007). Although some studies had demonstrated that ecosystem regeneration can be greatly enhanced by the presence of fine grained materials (Chu and Bradshaw, 1996; Dudeney et al., 2004; Kew et al., 2007) and the reduction of pebbles (Craw et al., 2007), none had simulated the original topsoil texture, as done in the present study in association with the quantification of the plant growth differences. In fact, the reduction of the grain size, to simulate the particles size distribution observed in the field, enhanced the availability of macro- and micro-elements that are essential for plants, thus facilitating E. erythopappus saplings development in a topsoil-lacking substrate. This process also increases surface contact among roots and the soil, facilitating cationic exchange and creating space for the buildup of organic and inorganic matter, in addition to facilitating the growth of roots and establishment of seeds (Ashby, 1997; Brady and Weil, 2008). The amelioration of plant performance in crushed laterite was also a consequence of soil texture change, since it defines porosity and permeability, controlling water fluxes and gaseous exchange, essential to plants growth. During the monitored period, the dynamics and the matric potential average values of the topsoil and crushed laterite did not differ, indicating that the performed particles size reduction was effective in creating similar conditions, in terms of water retention, to plant growth in both substrates. Although there hasn't been a significant difference, data (Fig. 4) shows that in twelve (from twenty) weeks during rainy season the average matric potential values were lower in crushed laterite. This pattern is more evident in the beginning of dry season. During this period, the crushed laterite reduced its matric potential more rapidly as compared to topsoil. That behavior may be a consequence of the distinct organic matter contents. Higher contents of organic matter, as in topsoil, increases soil water holding capacity, specially the water content available to plants. It occurs due to the influence of $\mathrm{OM}$ in soil structure, helping to build soil aggregation and producing a mixture of pore sizes, with greater water retention capacity in plants available ranges (Gupta and Larson, 1979; Hudson, 1994).

While crushed laterite may be more similar physically to topsoil than exposed laterite is to topsoil, the chemical properties of crushed laterite appear more similar to the chemical properties exposed laterite than they do the chemical properties of topsoil. With similar particle size distribution, topsoil has showed 22 times more total $\mathrm{N}$, in comparison to the crushed laterite treatment. As expected, topsoil also showed a higher total concentration in the immediately available fraction $(F 1)$ of the other elements. This reflected the actions of weathering and of organic matter on the formation and buildup of inorganic compounds in the soil (KabataPendias and Pendias, 2001), which was removed during mining, thus exposing the laterite. The chemical behavior of $\mathrm{Mn}, \mathrm{Fe}$ and S, elements that are responsible for the differentiation among topsoil and laterite groups, for component 1 of PCA, demonstrates this.
This result is not surprising since both the crushed and exposed laterites are new substrates, and these may develop chemical properties more like topsoil as they are exposed, over time. In other words, the improvement of substrate texture, thus, is the initial point of a long process of building a more fertile and organic soil.

Although E. erythropappus seedlings were planted during the transition period from the rainy to the dry season, and in spite of the minimal crop care applied during cultivation, i.e., without any soil $\mathrm{pH}$ correction or fertilization, the survival rate of the seedlings was high, even on the laterite. In fact, this species shows widespread distribution, occurring naturally in several environments and lithologies such as schists, quartzites and itabirites (Messias et al., 2013). The application of a thin layer of topsoil increased plant growth considerably, as expected (Holmes, 2001). However, the biomass allocation pattern of the species was not altered by the treatments with laterite, which only affected the speed of seedling growth (Muller, 2000). Reducing the grain size of laterite doubled the growth rate of plants in comparison to the plants grown on exposed laterite. Whiting et al. (2004) suggested that using plants with a slow growth rate, typical of stressful environments, was important to reducing the costs and increasing the success of restoration projects in metal-rich areas. Following these suggestions, E. erythropappus can be considered a suitable species for the revegetation of mined areas. Although an estimated cost of this method (using E. erythropappus + reduction of laterite particle size) has not been performed, it seems to be also advantageous in economic terms, especially in places where topsoil is not available. This method makes use of material (laterite) and machinery (crushers) available in the mining area itself, avoiding costs of soil purchase and transportation. Cost related to $\mathrm{pH}$ correction, fertilization and other cultivation cares, including labor hours, are also evidently reduced due to the high tolerance to adverse edaphic and climatic conditions of the native species E. erythropappus. A realistic estimate of the costs associated with this methodology, however, should be done in future work, especially when considering the coverage of large degraded areas.

Due to its intensive and uncontrolled exploitation during the last three centuries, the E. erythropappus has become an endangered species (Fundação Biodiversitas, 1997). Its extraction in natural areas is now under the control of state environmental agencies, which has developed several initiatives to encourage the production and planting of seedlings, and the sustainable management in particular areas. Moreover, this species has been target of studies in order to improve its growth patterns in different soil types, wood quality, as well as the production of alpha bisabolol, which has enormous commercial value (Souza et al., 2008). With advances in forestry science techniques and the commercial appeal, this species has been considered a promise for future large-scale commercial planting, what can contribute to local population income after mine closure. Although our study evaluated only one year of the juvenile plants development (just the most critical phase of plant establishment), the results found are very promising and suggest that E. erythropappus emerges as an alternative to the Eucalyptus planting in areas degraded by bauxite mining in Brazil.

\section{Conclusions}

Covering abandoned bauxite mine surface with crushed laterite, with a similar particles size distribution of patches with natural regeneration in the study area, proved to be a very promising technique for revegetation. This material, usually available and easy to create, can provide an alternative and effective substrate for plant growth, even if the growth occurs more slowly than compared to that in topsoil. E. erythropappus proved to be a promising species for planting in degraded mining areas where the topsoil is no longer 
available, with high rates of survival and growth, even without fertilizer. The species is found throughout Brazil and in several South American countries on various soil types, i.e., supporting wide range of soil and climate conditions. Such ecophysiological versatility associated with its economic potential are attributes that make it a potential species for commercial planting in the country and in other tropical and subtropical regions.

Although a simple reduction in particles sizes have proved to be effective concerning plant growth, this could be optimized by providing some source of organic matter. Further studies should test crushed laterite combined with easily obtained organic material, such as green waste, animal manure or biosolids obtained from urban water treatments.

\section{Acknowledgments}

This study was supported financially by the National Council for Scientific and Technological Development (CNPq), Project 577323/ 2008-3. Naiara A.M. Machado received fellowships from the Coordination for the Improvement of Higher Level Personnel (CAPES).

\section{Appendix A. Supplementary data}

Supplementary data related to this article can be found at http:// dx.doi.org/10.1016/j.jenvman.2013.07.006.

\section{References}

Aronson, J., Brancalion, P.H.S., Durigan, G., Rodrigues, R.R., Engel, V.L., Tabarelli, M., Torezan, J.M.D., Gandolfi, S., Melo, A.C.G., Kageyama, P.Y., Marques, M.C.M., Nave, A.G., Martins, S.V., Gandara, F.B., Reis, A., Barbosa, L.M., Scarano, F.R., 2011. What role should government regulation play in ecological restoration? Ongoing debate in São Paulo State, Brazil. Restoration Ecology 19, 690-695.

Ashby, W.C., 1997. Soil ripping and herbicides enhance tree and shrub restoration on stripmines. Restoration Ecology 5, 1-177.

Berrow, M.L., Wilson, M.J., Reaves, G.A., 1978. Origin of extractable titanium and vanadium in the A horizons of Scottish podzols. Geoderma 21, 89-103.

Fundação Biodiversitas, 1997. Lista das espécies presumivelmente ameaçadas de extinção da flora do estado de Minas Gerais. URL http://www.biodiversitas.org. br/listasmg/index.asp (accessed November 2011).

Bradshaw, A.D., 1997. Restoration of mined lands using natural processes. Ecological Engineering 8, 255-269.

Bradshaw, A.D., 2002. Introduction - an ecological perspective. In: Wong, M.H., Bradshaw, A.D. (Eds.), The Restoration and Management of Derelict Land: Modern Approaches. World Scientific Publishing, Singapore, pp. 1-6.

Brady, N.C., Weil, R.R., 2008. The Nature and Properties of Soils, 14 ed. Upper Saddle River, New Jersey.

Bremner, J.M.,1960. Determination of nitrogen in soil by the Kjeldahl method. The Journal of Agricultural Science 55, 11-33. http://dx.doi.org/10.1017/S0021859600021572.

Chu, L.M., Bradshaw, A.D., 1996. The value of pulverized refuse fines (PRF) as a substitute for topsoil in land reclamation. I. Field studies. Journal of Applied Ecology 33, 851-857.

COPAM (Environmental Policy State Council), 2008. Regulatory Deliberation Number 127. Establishes Guidelines and Procedures for Evaluation Mine Closure. http://www.siam.mg.gov.br/sla/download.pdf?idNorma $=8732 \quad$ (accessed November 2011).

Craw, D., Rufaut, C.G., Hammit, S., Clearwater, S.G., Smith, C.M., 2007. Geological controls on natural ecosystem recovery on mine waste in southern New Zealand. Environmental Geology 51, 1389-1400.

Dudeney, A.W.L., Tarasova, I.I., Tyrologou, P., 2004. Co-utilisation of mineral and biological wastes in mine site restoration. Minerals Engineering 17, 131-139.

Gupta, S.C., Larson, W.E., 1979. Estimating soil water retention characteristics from particle size distribution, organic matter percent, and bulk density. Water Resources Research 15 (6), 1633-1635.
Hall, S.L., Barton, C.D., Baskin, C.C., 2009. Topsoil seed bank of an Oak-Hickory forest in eastern Kentucky as a restoration tool on surface mines. Restoration Ecology $18,834-842$.

Hammer, Ø., Harper, D.A.T., Ryan, P.D., 2001. PAST: paleontological statistics software package for education and data analysis. Palaeontologia Electronica 4 (1)

Holmes, P.M., 2001. Shrubland restoration following woody alien invasion and mining: effects of topsoil depth, seed source, and fertilizer addition. Restoration Ecology 9, 71-84.

Hudson, B.D., 1994. Soil organic matter and available water capacity. Journal of Soil and Water Conservation 49 (2), 189-194.

Huxley, J., 1932. Problems of Relative Growth. Methuen, London.

IBRAM - The Brazilian Mining Association, 2010. Information and Analysis of the Brazilian Mineral Economy. URL http://www.ibram.org.br (accessed January 2011).

Jacobi, C.M., Carmo, F.F., Vincent, R.C., Stehmann, J.R., 2007. Plant communities on ironstone outcrops: a diverse and endangered Brazilian ecosystem. Biodiversity and Conservation 16, 2185-2200.

Kabata-Pendias, A., Pendias, H., 2001. Trace Elements in Soils and Plants. CRC Press, Florida.

Kew, G.A., Mengler, F.C., Gilkes, R.J., 2007. Regolith strength, water retention, and implications for ripping and plant root growth in bauxite mine restoration. Restoration Ecology 15, S54-S64.

Marschner, H., 1986. Mineral Nutrition of Higher Plants. Academic Press, London.

Mengler, F.C., Kew, G., Gilkes, R., Koch, J., 2006. Using instrumented bulldozers to map spatial variation in the strength of regolith for bauxite mine floor rehabilitation. Soil \& Tillage Research 90, 126-144.

Messias, M.C.T.B., Leite, M.G.P., Meira Neto, J.A.A., Kozovits, A.R., Tavares, R., 2013 Soil-Vegetation relationship in quartzitic and ferruginous brazilian rocky outcrops. Folia Geobotanica. http://dx.doi.org/10.1007/s12224-013-9154-4. (Online first).

Moutte, J., 2009. Analysis of Geological Materials by ICP-AES in Department of Geology, Saint-Etienne School of Mines. URL http://www.emse.fr/ moutte/ enplasma/IcpReportEng.pdf (accessed April 2009).

Muller I., 2000. The effect of nutrient availability on biomass allocation patterns in 27 species of herbaceous plants. Perspectives in Plant Ecology, Evolution and Systematics 3, 115-127.

Oliveira, A.D., Ribeiro, I.S.A., Scolforo, J.R.S., Mello, J.M., Acerbi Jr., F.W.A., Camolesi, J.F. 2009. Market chain analysis of Candeia Timer (Eremanthus erythropappus) Lavras. Cerne 15, 257-264. http://redalyc.uaemex.mx/src/inicio/ArtPdfRed.jsp? iCve $=74413021001$

Palmer, M.A., Ambrose, R.F., Poff, N.L., 1997. Ecological theory and community restoration ecology. Restoration Ecology 5, 291-300.

Parrotta, J., Knowles, O., 1999. Restoration of tropical moist forests on bauxitemined lands in the Brazilian Amazon. Restoration Ecology 7, 103-116.

Rauret, G., López-Sánches, J.F., Lück, D., Yli-Halla, M., Muntau, H., Quevauviller, Ph, 2001. The Certification of the Extractable Contents (Mass Fractions) of $\mathrm{Cd}, \mathrm{Cr}$ $\mathrm{Cu}, \mathrm{Ni}, \mathrm{Pb}$ and $\mathrm{Zn}$ in Freshwater Sediment Following Sequential Extraction Procedure - BCR 701. European Comission Brussels, Belgium.

Scolforo, J.R., Oliveira, A.D., Davide, A.C., Camolesi, J.F., 2003. Manejo Sustentado das Candeias. Eremanthus erythropappus (DC) Macleish e Eremanthus incanus (Less.) Less. Scientific Report, Lavras, Minas Gerais.

Shock, C.C., Barnum, J.M., Seddigh, M., 1998. Calibration of watermark soil moisture sensors for irrigation management. In: Irr Assn Proc Intl Irr Show, San Diego pp. 139-146.

Souza, A.T., Benazzi, T.L., Grings, M.B., Cabral, V., Silva, E.A., Cardozo-Filho, L., Antunes, O.A.C., 2008. Supercritical extraction process and phase equilibrium of Candeia (Eremanthus erythropappus) oil using supercritical carbon dioxide. The Journal of Supercritical Fluids 47 (2), 182-187.

Tordoff, G., Baker, A., Willis, A., 2000. Current approaches to the revegetation and reclamation of metalliferous mine wastes. Chemosphere 41, 219-228.

Valentin, J.L., 2000. Ecologia Numérica: Uma Introdução á Análise Multivariada de Dados Ecológicos. Publishing house Interciência, Rio de Janeiro.

Walkley, A., Black, I.A., 1934. An examination of the Degtjareff method for determining organic carbon in soils: effect of variations in digestion conditions and of inorganic soil constituents. Soil Science 63, 251-263.

Wentworth, C.K., 1922. A scale of grade and class terms for clastic sediments. The Journal of Geology 30 (5), 377-392.

White, P., Walker, J., 1997. Approximating nature's variation: selecting and using reference information in restoration ecology. Restoration Ecology 5, 338-349.

Whiting, S.N., Reeves, R.D., Richards, D.M., Johnson, S., Cooke, J.A., Malaisse, F. Paton, A., Smith, J.A.C., Angle, J.S., Chaney, R.L., Ginocchio, R., Jaffré, T., Johns, R. McIntyre, T., Purvis, O.W., Salt, D.E., Schat, H., Zhao, F.J., Baker, A.J.M., 2004 Research priorities for conservation of metallophyte biodiversity and their potential for restoration and site remediation. Restoration Ecology 12, 106-116. 